DOI: $10.17516 / 1997-1370-0750$

УДК 342.951

\title{
National Tax Security Assessment in the Tax Administration Mechanism
}

\author{
Karina A. Ponomareva and Kirill V. MasLov* \\ Dostoevsky Omsk State University \\ Omsk, Russian Federation
}

Received 16.03.2020, received in revised form 28.04.2021, accepted 11.05.2021

\begin{abstract}
The purpose of the article is to identify the essential features of indicators for national tax security and describe the system they comprise. The scope of the study is a comprehensive analysis of indicators for national tax security, aimed at identifying the nature of the correlation between the tax security and tax fairness indicators in interstate and domestic relations. Without understanding the essence and content of tax security indicators it is impossible to correctly assess the effectiveness of legal measures taken by states in the field of taxation.

The article considers the impact of the international economic integration process on the assessment of tax security of different states in the context of the concept of national interests. The discussion on the composition of tax security indicators is based on the impact made by various socio-economic phenomena on taxation. The comparative analysis of legal and economic literature shows that the variety of tax security indicators can be classified into literally tax indicators, other internal economic, foreign economic, managerial, legal, technical, socio-demographic, technological, military, political, climate indicators etc. For the quantitative evaluation of the threats on tax security, certain thresholds on the indicators are set.
\end{abstract}

Keywords: tax law, tax security, tax administration, indicators, national interests, BEPS Action Plan.

The reported study was funded by Russian Foundation of Basic Research (RFBR), project number 20-11-00292 "Legal support of national tax security in conditions of international economic integration".

Research area: financial law, tax law, budget law.

Citation: Ponomareva, K.A., Maslov, K.V. (2021). National tax security assessment in the tax administration mechanism. J. Sib. Fed. Univ. Humanit. Soc. Sci., 14(5), 669-679. DOI: 10.17516/19971370-0750.

\footnotetext{
(C) Siberian Federal University. All rights reserved

* Corresponding author E-mail address: karinaponomareva@gmail.com, mas_law@mail.ru ORCID: 0000-0002-2951-3067 (Ponomareva); 0000-0001-8384-277X (Maslov)
} 


\title{
Оценка налоговой безопасности государства
} в механизме налогового администрирования

\author{
K.А. Пономарева, К.В. Маслов \\ Омский государственный университет им. Ф. М. Достоевского \\ Российская Федерачия, Омск
}

\begin{abstract}
Аннотация. Цель статьи - выявить существенные особенности показателей национальной налоговой безопасности и описать их систему. Предметом исследования является комплексный анализ показателей национальной налоговой безопасности, направленный на выявление характера взаимосвязи между индикаторами налоговой безопасности и налоговой справедливостью в межгосударственных и внутригосударственных отношениях. Без понимания сущности и содержания индикаторов налоговой безопасности невозможна корректная оценка эффективности принимаемых государствами правовых мер в сфере налогообложения.

В статье рассмотрено влияние процессов международной экономической интеграции на оценку уровня налоговой безопасности государств в контексте концепции национальных интересов. В основе дискуссии о составе индикаторов налоговой безопасности лежит вопрос о степени влияния различных социальноэкономических явлений на налогообложение. Сравнительный анализ правовой и экономической литературы показывает, что все многообразие показателей налоговой безопасности наиболее полно можно разделить в зависимости от их характера на собственно налоговые показатели, другие внутриэкономические, внешнеэкономические, управленческие, правовые, технические, социальнодемографические, технологические, военные, политические, климатические показатели и др. Установление пороговых значений индикаторов позволяет количественно охарактеризовать степень воздействия угроз налоговой безопасности.
\end{abstract}

Ключевые слова: налоговое право, налоговая безопасность, налоговое администрирование, индикаторы, национальные интересы, план BEPS.

Исследование выполнено при финансовой поддержке РФФИ в рамках научного проекта № 20-11-00292 «Правовое обеспечение налоговой безопасности государства в условиях международной экономической интеграции».

Научная специальность: 12.00.04 - финансовое право, налоговое право, бюджетное право.

\section{Introduction}

Tax security of a state is the result of confronting specific threats on one hand and the measures taken by public authorities to minimize them on the other. The composition and intensity of threats to tax security are constantly changing, as well as the ways of countering such threats are being adjusted. Therefore, the current management task is to assess tax security in a particular state for the current period. Such an assessment is impos- sible without using a system of verifiable indicators of the tax security of the state, which, in its turn, requires specification of a list of such indicators based on the interpretation of their general and special features. Without applying the system of indicators to relations in the field of taxation at different stages of their development, it is impossible to correctly assess the effectiveness of measures taken to ensure the tax security of the state, including organizational and legal ones. Therefore, the defini- 
tion of a system of indicators is an important legal and managerial task, closely related to the problems of the goals of legal regulation and the quality of state tax administration. At the same time, there is no consensus in understanding the essence of tax security indicators and their structure both in the legal and economic literature.

\section{Theoretical Framework}

When defining the term "tax security of the state", or "national tax security", it is necessary to proceed from the established scientific approaches to the content of the categories of security and national security:

1) security as a characteristic of a complex system which is the society in its functioning and development (system approach) (Stepashin, 1994: 23; Polikarpov, 2001: 109);

2) security as a level of public relations that ensures their further sustainable development (sociological approach) (Mikhalkin, 1993);

3) security as a conscious need of the subject, value (axiological approach) (Rybalkin, 2006);

4) security as the activity of subjects to prevent threats (dynamic approach) (Timokhin, 1993: 30);

5) security as a state of object security (Tropin, 2004), absence of danger (Belov, 1994), threats (static approach) (Rozhdestvenskiy, 1995).

Thus, the terms that characterize certain types of national security are used classically both in legal studies and in legislation.

\section{Problem Statement}

Assessment of tax security in a particular state is an urgent management task in the current period. It is impossible to correctly assess the effectiveness of measures taken to ensure the tax security of the state, including organizational and legal measures, without a system of indicators applicable to the taxation relations at different stages of their development. Therefore, the determination of such a system of indicators is an important legal and managerial task, closely related to the goals of legal regulation and the quality of state tax administration. The present study aims to identify the essential features of indicators of tax security of the state and to describe their system.

\section{Methods}

The methodological basis of the research consists of both general scientific methods (dialectical-materialistic method, induction, deduction, analysis, synthesis) and interdisciplinary methods (simulation and sociological methods), as well as specific legal methods of study.

The research is based on the principle of truth, unity of theory and practice; the principles of objectivity, comprehensiveness and complexity of the study; the principle of interdisciplinary research (using the achievements of legal and economic science); systematic approach principle.

The specific legal methods are the formal-legal method and the comparative method. The formal-legal approach allows identifying the information array to be further analysed. The information will be accumulated and delimitated based on the criterion of compliance with the subject of legal regulation.

\section{Discussion \\ Tax Security and Tax Fairness}

A significant share of tax sources in the budget revenues determines the key role played by the tax revenues in the stable economic development and national security. Besides, threats to national fiscal interests cannot be eliminated only by means of legislation, which predetermines the interaction of states in the tax sphere. The importance of tax security of the state is dramatically increasing. This is also due to the trends based on international economic integration: the increasing influence of transnational corporations on the national economy, the growing number of cross-border transactions, the increasing mobility of taxpayers, and the integration of financial instruments. The development of legal solutions to minimize threats to tax security is complicated by the need of the states to cooperate and unite their efforts.

There are many concepts in national and international tax law closely related to tax security. For instance, countries, international 
organizations $(\mathrm{OECD})^{1}$ and supranational organizations (EU) have referred to the concept of fairness in taxation. Countries describe fairness in a juridical sense addressing equality, non-discrimination and procedural fairness. The instruments used are constitutions, national legislation and taxpayer charters.

However, at the international level, the discussion goes further than juridical fairness. Countries also refer to fair tax competition (among countries) and fair taxation (between countries and taxpayers). This constitutes an approach not only from an economic perspective (violations of fair economic competition; equitable distribution of tax burden; competitiveness issues; payment of taxes at the place of profit generation; level-playing field) (Burgers, Mosquera Valderrama, 2017: 780) but also a political and juridical perspective (i.e. fair share and justice). The different approaches to fairness may have implications for tax competition and the reaction to abusive practices of taxpayers as well as states. For instance, the European Commission addressed fairness in the 2012 Action Plan to strengthen the fight against Tax Fraud and Tax Evasion ${ }^{2}$ to "provide a comprehensive and effective response to the various challenges posed by tax fraud and evasion and can thus contribute to increasing the fairness of Member States' tax systems, to securing much needed tax revenues and ultimately to improve the proper functioning of the internal market"3.

\section{National Interests \\ in the Tax Area Determining Indicators of Tax Security}

The indicators of state tax security are directly derived from the values that characterize security and the threats that affect them.

The concept of interests is used in normative acts, other official documents and scientific literature to determine the values that are protected.

\footnotetext{
OECD (2013). Action Plan on Base Erosion and Profit Shifting, OECD Publishing. Available at: https://www.oecd. org/ctp/BEPSActionPlan.pdf at 8 .

2 Communication from the Commission to the European Parliament and the Council, An Action Plan to strengthen the fight against tax fraud and tax evasion, COM/2012/722 final, at 6 . 3 Ibid., at 15 .
}

The term "national interests" is also used in the definition of the corresponding type of security contained in the economic security Strategy of the Russian Federation for the period up to 2030 (Decree of the President of the Russian Federation of 13 May 2017 No. 208 "On the economic security Strategy of the Russian Federation for the period up to 2030"). It replaced the "vital interests" category in the previous Strategy. This replacement seems justified, since the attribute of "vitality" is correlated with the needs of the individual, but not the state.

We assume that the definitions of state (national) interests proposed by scholars do not include specific features and are too general, for example: "the total need of the state in both internal and external aspects to ensure the security and sustainable development of the individual, society and the state" (Iurchenko, Davydov, 2011: 172).

National interests in the economic sphere are clearly defined in the Strategy for the economic security of the Russian Federation for the period up to 2030: these are objectively significant economic needs of the country, the satisfaction of which ensures the implementation of strategic national priorities of the Russian Federation. The given definition emphasizes such features of national interests as objectivity, absolute necessity and strategic importance. However, the definition of national interests through the use of the category "national priorities" does not correspond to the logical principles of definition due to the synonymy of these categories. Besides, national interests can be considered objective only in the sense that they exist as a phenomenon regardless of the consciousness of the subject who perceives them. However, the specific list of national interests, including interests in the area of taxation, in addition to the impact of economic laws, is largely determined by the unique traditions and institutions of each state and therefore should be considered as subjective.

National interests in the tax sphere can be defined as objective needs for collecting all categories of tax payments to budgets that are necessary and sufficient for current and future financing of all functions and tasks of the state 
and municipalities, modified to meet public requests.

The current study shows that the importance of the legal provision of tax security in the modern world is significantly increasing. This is due to trends based on international economic integration: the increasing influence of multinational enterprises on the national economy, the increase of the number of cross-border transactions, increased mobility of taxpayers, the integration of financial instruments. The development of legal solutions to minimize the threats caused by this is complicated by the need of the states to unite their efforts within the framework of supranational entities.

In this regard, the states have the right to counter practices that undermine the effectiveness of their tax jurisdiction. The reaction of tax systems to such practices should vary along with the intensity of the danger for the collection of taxes. Therefore, a stronger reaction should be opposed to phenomena such as tax evasion and tax fraud, since in such circumstances there is an open violation of law and, in the former case, the taxpayer even tries to hide such violation by willful behaviours. However, there are additional dangerous phenomena that may undermine the effective collection of taxes. Such phenomena consist in the circumvention of the liability to tax by creating friction between form and substance that frustrates the spirit of the law. The main conceptual reference for this type of situations is tax avoidance.

It is discussed whether there is an international obligation to counter abusive tax practices. The answer to this question is complex and requires distinguishing between the two of them and between the national and the international level. At the national level, each state is interested in countering the open violation of its law and thus in protecting the integrity of its tax revenues. At the international level, significant differences arise as to how the various systems detect such phenomenon, thus making it more complex to determine whether there is an international obligation to counter tax evasion.

Changes in Russian tax legislation introduced in recent years are largely due to the use of the experience of international organizations, in particular, the OECD. The devel- opment of Russian tax legislation is influenced by the acts of these organizations, first of all, OECD Action Plan on Base Erosion and Profit Shifting (hereinafter - the BEPS Action plan ${ }^{4}$. Fixing in the Tax Code of the Russian Federation of $\mathrm{CFC}$ rules, transfer pricing rules, thin capitalization rules, beneficial owner concept, criteria for tax residency of legal entities, and ratification by the Russian Federation of the Convention on mutual administrative assistance in tax matters and the OECD Multilateral Convention to Implement Tax Treaty Related Measures to Prevent Base Erosion and Profit Shifting $\left(\mathrm{MLI}^{5}\right)$ are milestones of Russian tax policy at the present stage. The fact of ratification of MLI by Russia, of course, requires reflection and study from the standpoint of tax security.

\section{The Constitutional Legal Conditionality of Indicators of the Tax Security}

Stakhov notes the identity of the interests protected by security and values enshrined in the Constitution (Stakhov, 2007: 17). In a legal state, a necessary condition for ensuring security in any sphere, its most important indirect indicator, is the consolidation of the relevant values in the basic law.

The Constitution of the Russian Federation declares human rights and freedoms to be the highest value (Article 2), and the goal of state policy is to create conditions that ensure a decent life and free development of a person (part 1 of Article 7). Therefore, an integral element of the system of indicators of tax security of the state is the level of investment in the development of human capital. Human capital is a stock of knowledge, skills, motivations, abilities and health that is formed as a result of investment (Dobrynin, Diatlov, 1999: 6-7) and contributes to the growth of income not only for the individual but also for the state as a whole (Mill, 1980: 139). Thus, "human

\footnotetext{
4 OECD Action Plan on Base Erosion and Profit Shifting. OECD Publishing. Available at: http://dx.doi. org/10.1787/9789264202719-en

5 Multilateral Convention to Implement Tax Treaty Related Measures to Prevent Base Erosion and Profit Shifting. Available at: http://www.oecd.org/tax/treaties/multilateral-convention-to-implement-tax-treaty-related-measures- to-preventBEPS.pdf
} 
capital can also be spoken of as a factor of national wealth" (Kostiukov, 2010: 5). The Nobel laureate T. Schultz proved that investments in human capital in comparison with investments in classical capital bring more income (Schultz, 1971). Currently, Russia ranks only $49^{\text {th }}$ in the world rating of countries on the human development index (an indicator that uses almost the same elements that characterize human capital). A high level of taxation that discourages economic activity of the population, as well as a balanced budget due to the refusal of public investment in health and education in the future inevitably undermine the tax base of the state, and therefore threaten the tax security of the state.

These threats are also of particular relevance for international and supranational associations. For example, differences in the tax burden between enterprises from different member states operating in the same market violate the principle of neutrality of capital in situations, in which national investors abroad will not be put in conditions worse than those of others. The need to take into account a large number of national tax systems simultaneously creates a significant administrative burden, especially in the field of transfer pricing and cross-border movement of income. Such differences pose a problem not only for businesses, but also for the member states that face aggressive tax planning, tax evasion, and tax base erosion (Van Thiel, Rattra, Meer, 1990).

Therefore, indicators of tax security of the state should include indicators of ensuring the economic needs of all social groups.

\section{The Classification of the Indicators of the Tax Security}

Savin divides economic security indicators into production-financial and socio-demographic indicators (Savin, 2010: 19-20). This classification is also applicable to tax security indicators. The criterion that is based on it can be called the essence of the indicator. However, the types highlighted by the author are not exhaustive, they do not cover the entire volume of indicators.

In our opinion, the most complete variety of tax security indicators, depending on their nature, characterizes their division into literally tax indicators, other internal economic, foreign economic, managerial, legal technical, socio-demographic, technological, military, political, climate indicators etc.

Kozyrev calls the inefficiency of the tax system (the inability to implement fiscal and regulatory functions) and its instability (the inability to support external and internal investments) as the key factors affecting the tax security of the state (Kozyrev, 2004: 13-14). In such a classification, questions are raised about both its grounds and the content of the selected species. However, the idea of the relationship between tax security indicators and the functions performed by taxes seems to be fruitful. In this regard, the division of indicators into direct and indirect ones takes on a new meaning. Direct indicators are indicators that reflect the implementation of the fiscal function of the tax system, which affects the state of tax security exclusively. Indirect indicators are related to the implementation of the regulatory function of the tax system, which also affects other components of economic security (the level of social stratification, competition, etc.), as well as reverse determination.

Indicators can be divided into general (at first approximation we understand them as characterizing the state of not only tax security, but also other components of national security), and special ones (related exclusively to tax security).

By analyzing the indicators of the Russian Federation's economic security strategy for the period up to 2030, it is possible to identify the following special indicators of the state's tax security:

- the federal budget deficit, including the non-oil and gas deficit of the federal budget;

- the deficit of the consolidated budget of the subjects of the Russian Federation;

- the tax crime rate;

- the tax collection rate.

Special tax security indicators should reflect the sufficiency of tax revenues collected in budgets of all levels for performing public functions and tasks. Therefore, the list of direct indicators should be supplemented with the fol- 
lowing managerial, economic, and legal-technical indicators.

Managerial indicators are the key for assessing the tax security of the state, since the quality of state administration of taxation and economic processes, in general, directly determines the economic and other systems of the state as objects of administration, and therefore the value of economic, socio-demographic and other indicators. The effectiveness of budget planning and tax administration can be attributed to the number of administrative indicators of the state's tax security. If the budget expenditure forecast is incorrect, even with high tax collection rates, the revenue received will not be sufficient to perform the functions and tasks of the state. Errors in tax revenue planning cause an artificial underestimation of other indicators of tax security, such as tax collection, budget execution with a deficit. The revealed regularities emphasize the relationship between the state administration of taxation and the budget and the need for coordination between them in ensuring the tax security of the state and national security in general. There are significant reserves for improving the efficiency of state tax administration in Russia. According to independent experts, Russia is among the world leaders in terms of using information technologies in tax administration (Interfax.ru, 2017). However, according to the indicator "Paying Taxes" in the Doing Business 2020 Russia is ranked $58^{\text {th }}$ out of 190 countries (World Bank, 2020).

There are the following economic factors that can be distinguished: tax collection rate, tax potential of a territory, the ratio of the tax burden rate and GDP, the ratio of the average tax burden rate and the industry average profitability (Mironova, 2016), the ratio of taxed and real income; the ratio of consumption expenditure and declared income of the population, the hidden employment rate (Krokhina, 2003: 336-337).

Special legal technical indicators include the number of gaps and conflicts in the legislation regulating relations in the field of taxation, as well as the number of changes in such legislation during the calendar year.

It is difficult to agree with the opinion that the tax structure, the ratio of direct and indirect taxes, and information about the tax base are indicators of tax security (Chelysheva, 2010: 33). Although these indicators characterize certain elements of a state's tax system, they hardly correlate with the collection of taxes to budgets.

General indicators of state tax security can be identified by analyzing economic security indicators that affect the tax system. The first domestic researchers of economic security issues formulated its most general indicators: independence of the national economy, its stability, the ability to constantly update and improve themselves (Denezhkina, Suzdaleva, 2011: 98), economic potential sufficient for independent, sustainable, progressive development of all spheres of public life; the ability of a country to reproduce itself and provide for its population according to recognized international standards ... the well-being of all segments of the population (Tarasov, 2013: 18), "sufficient defence potential" (Senchagov, 2008: 30). The analysis of scholars' views allows us to identify signs of such indicators that are indirect indicators of tax security: independence, stability and development of the national economy, sufficient economic resources for the effective performance of state functions, especially in the defence and social spheres.

A. Illarionov rightly notes that the most important indicators of economic security are, firstly, the country's economic development rate, determined by the value of the produced gross domestic product per capita, and secondly, the economic growth, characterized by the value of the growth rate (fall) of the gross domestic product per capita (Illarionov, 1999: 79). These indicators are also important for tax security, as they determine the dynamics of the development of the tax base, and, ultimately, the prospect of tax revenues entering the budgets.

In general, ensuring tax security should not come at the expense of other elements of the state's economic system, as well as undermine other areas of public life: economic, military-political, and socio-cultural. The stability and development of these areas are among the most important indirect indicators of the state's tax security. 


\section{Threshold Values of Indicators of the Tax Security}

As noted in the economic literature, in identifying the state of tax security, the primary role is played not so much by its indicators themselves, as by their maximum, threshold values (Senchagov, 2007: 12). We believe that it is not quite correct to methodologically separate indicators and their threshold values in the context of their significance for tax security. Threshold values are not an independent phenomenon, but an attribute of the indicator that allows you to more accurately assess the impact of security threats. In other words, setting thresholds allows characterizing the indicators quantitatively, not qualitatively.

Having refined the existing scientific definition of "threshold values of security threats" as a cause of the destruction of state systems (Shkvarok, 2009: 7; Chelysheva, 2010: 34), we can propose the following definition of tax security indicators in the quantitative aspect. These are measurable critical indicators that exist at a certain point in time and change depending on changes in the tax and other systems of the state, deviation from which leads to their complete or partial destruction or a slowdown in their development.

The need to use indicators in the process of ensuring tax security by public authorities requires selecting an adequate system of assessment methods. Determining the quantitative expression of such indicators is the prerogative of economic science. Thus, Glaz'ev, who developed 22 measures of economic security, assessed the threshold of the gap between the incomes of $10 \%$ most high-and low-income populations at 8 times the unemployment rate of 7\% (Glaz'ev, Lokosov, 2012: 587).

Savin gave the following thresholds for direct and indirect indicators: "economic growth (less than $0.5-1.5 \%$ per year); the ratio of budget deficit to GDP (less than 4\%); the level (rate) of inflation (at least 1\% and not more than $6 \%$ ); the ratio of resources involved in the shadow turnover to GDP (the prevalence of the shadow economy) (20\%)" (Savin, 2011: 9). The current value of the latter indicator is estimated by law enforcement agencies at 40 -
$50 \%$, and by independent experts at $20-80 \%$ (Savin, 2011: 20).

Since all the indicators interact in the system, a security threat is characterized by exceeding the acceptable limits of threshold values even for one indicator. Thresholds for some indicators should not be reached at the expense of others. Predictive analysis of the impact of legal acts on the dynamics of economic security indicators should be carried out not only concerning laws and important government decisions but also to other regulatory legal acts of the administration. Consideration of thresholds is also important at the regional level. As indicators of tax risk allow assessing the condition of the object of government in making any tax management-related decisions, we consider it proper to provide in the regulations for the Government of the Russian Federation, internal regulations of the Ministry of Finance of Russia and Federal Tax Service of Russia the necessity of monitoring of these indicators, as well as modelling the changes in their values due to the implementation of acts of the state administration of taxation.

\section{Conclusion}

Indicators of tax security of the state are a system of qualitatively separate and quantitative indicators which allow assessing the probability of receipt of tax payments to the budget and which are sufficient to finance all the functions and tasks of the state and municipalities, both in the current period and in the future.

The composition of tax security indicators determines national interests in the tax sphere based on the Constitution of the state.

Special indicators of tax security should reflect the sufficiency of tax revenues collected into budgets of all levels to perform public functions and tasks and include a system of management (efficiency of budget planning and tax administration), economic (federal budget deficit, including non-oil and gas deficit of the federal budget; deficit of the consolidated budget of the subjects of the Russian Federation; tax crime rate, tax collection rate) and legal technical indicators (the number of gaps and conflicts in tax legislation, as well as the 
number of changes in such legislation during the calendar year).

General indicators of tax security of the state should include indicators of ensuring the economic needs of all social groups. The main ones are independence, stability and development of the national economy, the sufficiency of economic resources for the effective performance of state functions, especially in the defence and social spheres, correlated with the value of the gross domestic product produced per capita and the value of the growth rate (fall) of the gross domestic product per capita.

Determining the quantitative expression of such indicators is the prerogative of economic science. The regulations of the Government of the Russian Federation, as well as financial authorities at all levels of government and tax authorities, should provide mandatory monitoring of these indicators, as well as modelling changes in their values due to the implementation of state tax administration acts.

\section{References}

Becker, G.S. (1964). Human capital: theoretical and empirical analysis, with special reference to education. Chicago, London: The University of Chicago Press. 390 p.

Belov, P.G. (1994). Sistemnye osnovy obespecheniia natsional'noy bezopasnosti Rossii [Systematic basis for ensuring national security of Russia]. In Bezopasnost' [Security], 6, 88-94.

Burgers, I.J.J., Mosquera Valderrama, I.J. (2017). Fairness: A Dire International Tax Standard with No Meaning? Intertax, 45(12).

Chelysheva, E.A. (2010). Sistema nalogovoy bezopasnosti i razvitie ee normativno-pravovogo obespecheniia [System of tax security and development of its legal support]. In Terra Economicus, 8 (3), part 3, 31-37.

Decree of the President of the Russian Federation of 13 May 2017 No. 208 "On the economic security Strategy of the Russian Federation for the period up to 2030".

Denezhkina, I.E., Suzdaleva, D.A. (2011). Sistema pokazateley dlia monitoringa ekonomicheskoy bezopasnosti regiona [Indicator system for the economic security monitoring of the region]. In Strategic decisions and risk management, 3, 96-101.

Dobrynin, A.I., Dyatlov, S.A., Tsyrenova, E.D. (1999) Chelovecheskiy kapital v tranzitivnoy ekonomike: formirovanie, otsenka, effektivnost' ispol'zovaniya [Human capital in a transitive economy: formation, evaluation, efficiency of use]. St. Petersbirg: Nauka, $360 \mathrm{p}$.

Glaz'ev, S.Iu. (1997). Osnova obespecheniia ekonomicheskoy bezopasnosti strany - al'ternativnyy reformatorskiy kurs [The basis for ensuring the economic security of the country - an alternative reformist course]. In Rossiiskiy ekonomicheskiy zhurnal [Russian economic journal], 1, 3-19.

Glaz'ev, S.Iu., Lokosov, V.V. (2012). Otsenka predel'no kriticheskikh znacheniy pokazateley sostoianiia rossiyskogo obshchestva i ikh ispol'zovanie v upravlenii sotsial'no-ekonomicheskim razvitiem. Kakimi dolzhny byt' pokazateli moderniziruemoy ekonomiki? [Evaluation of extremely critical values of indicators of the state of Russian society and their use in the management of socio-economic development. What should be the indicators of the modernizing economy?]. In Vestnik Rossiiskoi akademii nauk [Herald of Russian Academy of Sciences], 7, 587-604.

Illarionov, A. (1999). The Criteria of Economic Security. In Problems of Economic Transition, Taylor \& Francis Journals, 41(12), 63-92.

Iliukhin, V.I. (1999). Natsiia - gosudarstvo - bezopasnost'. Voprosy teorii i praktiki [Nation-state-security. Questions of theory and practice]. Moscow, Tsentrkniga, $132 \mathrm{p}$.

Iurchenko, M.V., Davydov, A.V. (2011). Nauchno-teoreticheskie osnovaniia kategorii "natsional'naia bezopasnost' Rossii" [Scientific and theoretical foundations of the category "national security of Russia"]. In Vestnik Buriatskogo gosudarstvennogo universiteta [Bulletin of Buryatia State University], 6, 169-173.

Interfax.ru (2017). Available at: http://www.interfax.ru/business/559809 (accessed 15 September 2019).

Kozyrev, A.A. (2004). Vliianie instituta otvetstvennosti za nalogovye pravonarusheniia na ekonomicheskuiu bezopasnost' gosudarstva [The impact of the Institute of responsibility for tax offences on the economic security of the state. Cand. Diss. Thesis]. Saratov, 24 p. 
Kostiukov, A.N. (2010). Prioritety konstitutsionno-pravovogo razvitiia sovremennoy Rossii [Priorities of constitutional and legal development of modern Russia]. In Konstitutsionnoe i munitsipal'noe pravo [Constitutional and municipal law], 1, 3-13.

Krokhina, Iu.A. (ed.). (2003). Nalogovoe pravo Rossii: uchebnik [Tax law of Russia: textbook]. Moscow, Norma, $656 \mathrm{p}$.

Mayorova, E.N. (2016). O kriteriiakh obespecheniia ekonomicheskoy bezopasnosti Rossii [On criteria of ensuring economic security of Russia]. In Vestnik Ural'skogo instituta ekonomiki, upravleniia i prava [Bulletin of the Ural Institute of Economics, Management and Law], 4, 24-30.

Mikhalkin, N.V. (1993). Bezopasnost' Rossiiskoy Federatsii. Voprosy teorii i praktiki [The security of the Russian Federation. Theory and practice issues]. Moscow, Ministry of Defence of the Russian Federation, $114 \mathrm{p}$.

Mill, J.S. (1980). Osnovy politicheskoy ekonomii [Fundamentals of political economy], vol. 1. Moscow, Progress Publ., 479 p.

Mironova, O.A. (2016). Nalogovaia bezopasnost': razvitie teorii, metodologii i praktiki [Tax security: development of theory, methodology and practice. In Innovatsionnoe razvitie ekonomiki [Innovational development of economics], 3-1(33), 90-97.

Polikarpov, V.S. (2001). Filosofiia bezopasnosti [Philosophy of security]. Taganrog, Taganrog Technical University Press, $168 \mathrm{p}$.

Rayzberg, B.A., Lozovskiy, L.Sh., Starodubtseva, E.B. (2011). Sovremennyy ekonomicheskiy slovar' [The modern economic dictionary]. Moscow, INFRA-M.

Rozhdestvenskiy, Iu.V. (1995). Bezopasnost' Rossii i slovesnost' (tezisnye suzhdeniia) [Security of Russia and the literature (thesis assertions). In Bezopasnost' [Security], 3, 83-88.

Rybalkin, N.N. (2006). Filosofiia bezopasnosti [The philosophy of security]. Moscow, MPSI, 296 p.

Savin, Iu.V. (2011). Obespechenie ekonomicheskoy bezopasnosti v biudzhetno-nalogovoy sisteme Rossiyskoy Federatsii: avtoref. dis. ... kand. ekon. nauk [Ensuring economic security in the budget and tax system of the Russian Federation. Cand. Diss. Thesis]. Moscow, 24 p.

Shatunova, N.N (2008). Ugrozy ekonomicheskoy bezopasnosti gosudarstva: sushchnost', vidy, sistema indikatorov [Threats to the economic security of the state: essence, types, the system of indicators]. In Vestnik OrelGIET [OrelGIET Bulletin], 1, 80-88.

Shkvarok, V.M. (2009). Teoreticheskie osnovy i klassifikatsiia ugroz ekonomicheskoy bezopasnosti Rossii: avtoref. dis. ... kand. ekon. nauk [Theoretical bases and classification of threats to the economic security of Russia. Cand. Diss. Thesis]. Saint-Petersburg, 27 p.

Schultz, T. (1971). Investment in human capital; The role of education and research, New York, The Free Press, 1971, xii +272 pp.

Shumilov, V.M. (2014). Mezhdunarodnoe ekonomicheskoe pravo: uchebnik dlia magistrov [International economic law: textbook for masters]. Moscow, Iurayt Publishing House, 612 p.

Senchagov, V.A. (2007). Ekonomicheskaia bezopasnost' Rossii [The economic security of Russia]. In ECO, 5, 2-22.

Senchagov, V.A. (2008). Metodologiia obespecheniia ekonomicheskoy bezopasnosti Rossii [The methodology of economic security provision in Russia]. In Ekonomika regiona [Economy of region], 3, 28-39.

Sorokin, K.E. (1996). Natsional'nye interesy Rossii: geopoliticheskiy aspekt [National interests of Russia: geopolitical aspect]. In Vestnik Rossiyskogo gumanitarnogo nauchnogo fonda [Bulletin of the Russian Humanities Science Fund], 2, 47-52.

Stakhov, A.I. (2007). Administrativno-publichnoe obespechenie bezopasnosti v Rossiyskoy Federatsii: avtoref. dis. ... dokt. iurid. nauk [Administrative and public security in the Russian Federation. Doct. Diss. Thesis]. Moscow, $34 \mathrm{p}$.

Stepashin, S.V. (1994). Bezopasnost' cheloveka i obshchestva. Politiko-pravovye voprosy [The safety of man and society. Political and legal issues]. Saint Petersburg, St Petersburg MIA Law Institute, 240 p.

Tarasov, M.E. (2013). Bezopasnost'v sfere ekonomiki i finansov [Security in the field of economics and finance]. Moscow, Kontsep, 300 p. 
Timokhin, P.P. (1993). K formirovaniiu kontseptsii bezopasnosti Rossii [To the formation of the concept of Russia's security]. In Bezopasnost' [Security], 6, 30-56.

Tropin, S.A. (2004). Ekonomicheskaia bezopasnost' Rossii [Economic security of Russia]. In Zakonodatelstvo i ekonomika [Legislation and economics], 5, 31-35.

Van Thiel, Rattra, Meer (1990). Corporate Income Taxation and Internal Market Without Frontiers. 30 European Taxation 11 (1990).

World Bank (2020). Doing Business 2020: Comparing Business Regulation in 190 Economies. Washington, DC: World Bank. DOI: 10.1596/978-1-4648-1440-2. Available at: https://openknowledge.worldbank. org/handle/10986/32436 (accessed 15 February 2021). 